\title{
Use of homogenized drone semen in a bee breeding program in Western Australia
}

\author{
M.E. Kühnert ${ }^{1}$, M.J. Carrick ${ }^{2}$ and L.F. Allan ${ }^{2}$ \\ $1 \mathrm{J.W}$. Goethe Universität Frankfurt am Main, Fachbereich Biologie, Institut für Bienenkunde, (Poly- \\ technische Gesellschaft), Karl von Frisch Weg 2, 6370 Oberursel, FRG \\ 2 Western Australian Department of Agriculture, Animal production, bee keeping section, Baron-Hay \\ Court, South Perth, WA 6151, Australia
}

(received 20 January 1989, accepted 10 July 1989)

Summary - The use of mixed sperm of a large number of drones is considered to be advantageous in maintaining honey bee stock (Apis mellifera $\mathrm{L}$ ). The new technique of using homogenized drone semen was applied in a commercially orientated breeding program in Western Australia. Over a period of 5 years the insemination success averaged $85 \%$. Queens started oviposition 4.35 days after insemination (S.E. $=0.15 ; n=467$ ). Over 4 years brood viability ranged from $88 \%$ to $94 \%$ (S.E. $=0.66$ ) and colonies built up very quickly. Honey production averaged $115 \mathrm{~kg}$ per hive in 1986 and $109 \mathrm{~kg}$ in 1987 (S.E. = 2.80). Longevity of queens was not appreciably different from that of queens reported in the literature that were inseminated with non-homogenized semen.

Apis mellifera - breeding program - instrumental insemination - mixing of spermatozoa

\section{INTRODUCTION}

Artificial selection and small breeding populations cause a loss of genes. This results in decreasing performance from inbreeding depression (Mackensen, 1951; Plass, 1953; Moritz, 1981). In recently published breeding theory (Chevalet and Cornuet, 1982a; Page and Laidlaw, 1982a, 1982b; Page and Marks, 1982; Page et al., 1982, 1983; Moran, 1983; Moritz, 1984a), ways to minimize inbreeding and maximize genetic variability were suggested. Based on the work of Kaftanoglu and Peng (1980), Moritz (1983) used mutant markers to demonstrate the effica- cy of diluting drone semen. Subsequent centrifugation following dilution results in the virtual homogenous mixing of the spermatozoa. Homogenized semen of a large number of drones is considered the optimum way to maintain honey bee stocks over many generations for the following reasons: inbreeding is avoided since genetic diversity is maintained by inseminating each queen with genetic material of a maximum number of drones. Since all queens are inseminated with identical semen, queen evaluation is more precise, as genetically caused colony differences are attributed to differences in the queens themselves. 
In 1980 a honey bee breeding program was started in Western Australia. Initially Italian-type bees were screened from Western Australian sources. Isolated natural matings on an island were used to improve or maintain stock. Since 1983 the program has been modeled after closed breeding systems suggested by Page and Laidlaw (1982a, 1982b); Page and Marks (1982); Page et al., (1982); Page et al., (1983) and Moran (1983). The closed population artificial breeding system was modified by including a $16 \%$ contribution of semen from the best progeny of carefully selected queens from the general population. This is similar in concept to an open selection system discussed by Chevalet and Cornuet (1982b). In the Australian breeding program stock is maintained by instrumentally inseminating (II) queens (Mackensen and Roberts, 1948; Ruttner, 1975) with homogenized semen from a very large number of drones.

The objectives of this paper are :

1) To evaluate the performance of queens inseminated with homogenized semen from a large number of drones.

2) To demonstrate the feasibility of using homogenized drone semen in a practical breeding program.

\section{METHODS}

\section{Bee breeding program}

The central breeding apiary consisted of 100 colonies, 20 lines with 5 daughter queens per line (Fig. 1). Each year the most productive queen in each line produced 5 daughters. Drones from each of the selected queens contributed an equal volume of semen to a semen pool. Daughter queens were inseminated with homogenously mixed semen from this pool. For influx of new genes, 4 queens were selected from 15 to 20 breeder hives, contributed by the beekeeping industry each year. These queens produced 5 daughters each, which were inseminated with semen from the same semen pool. Only the top performing daughter from the inputqueens, out of each group of 5 , produced drones that contributed to next year's semen pool. Genetic material of unrelated queens was thus continuously introduced into the gene pool.

\section{Drones and semen collection}

Drones were reared according to Ruttner (1980). When they were more than 16 days of age, equal volumes of semen from drones of each line were collected in $50 \mu \mathrm{l}$ glass capillary pipettes, (Ruttner, 1975; Schley, 1983; Harbo, 1985; Laidlaw, 1985) which were sealed with Tris buffer-diluent and stored at $15^{\circ} \mathrm{C}$ (Poole and Taber, 1970) until homogenization (up to 3 days later).

\section{Diluents}

A Tris buffer (Verma, 1978; Williams and Harbo, 1982; Moritz, 1984b) was used to dilute the semen before centrifuging. The contents of the diluent were: $\mathrm{NaCl}(1.1 \%)$, glucose $(0.1 \%)$, LArginine $\mathrm{HCl}-(0.01 \%)$, L-Lysine-HCL $(0.01 \%)$, dissolved in a $0.05 \mathrm{M}$ buffer (Tris-(hydroxymethyl) amino methane, Tris-(hydroxymethyl) amino methane hydrochloride (Sigma, Munich) (in distilled water) adjusted to $\mathrm{pH}$ 8.7-8.9. Streptomycin sulfate $(0.02 \%)$ and penicillin G-K salt $(0.01 \%)$ were added shortly before use.

\section{Semen homogenizing}

Equal amounts of semen from each line were combined with Tris buffer diluent (about 12 times the volume of semen). Sterile Eppendorf tubes $(0.4 \mathrm{ml})$ were fitted to disposable syringes $(2 \mathrm{ml})$ without plunger and served as centrifuge vessels in a standard bench centrifuge with 


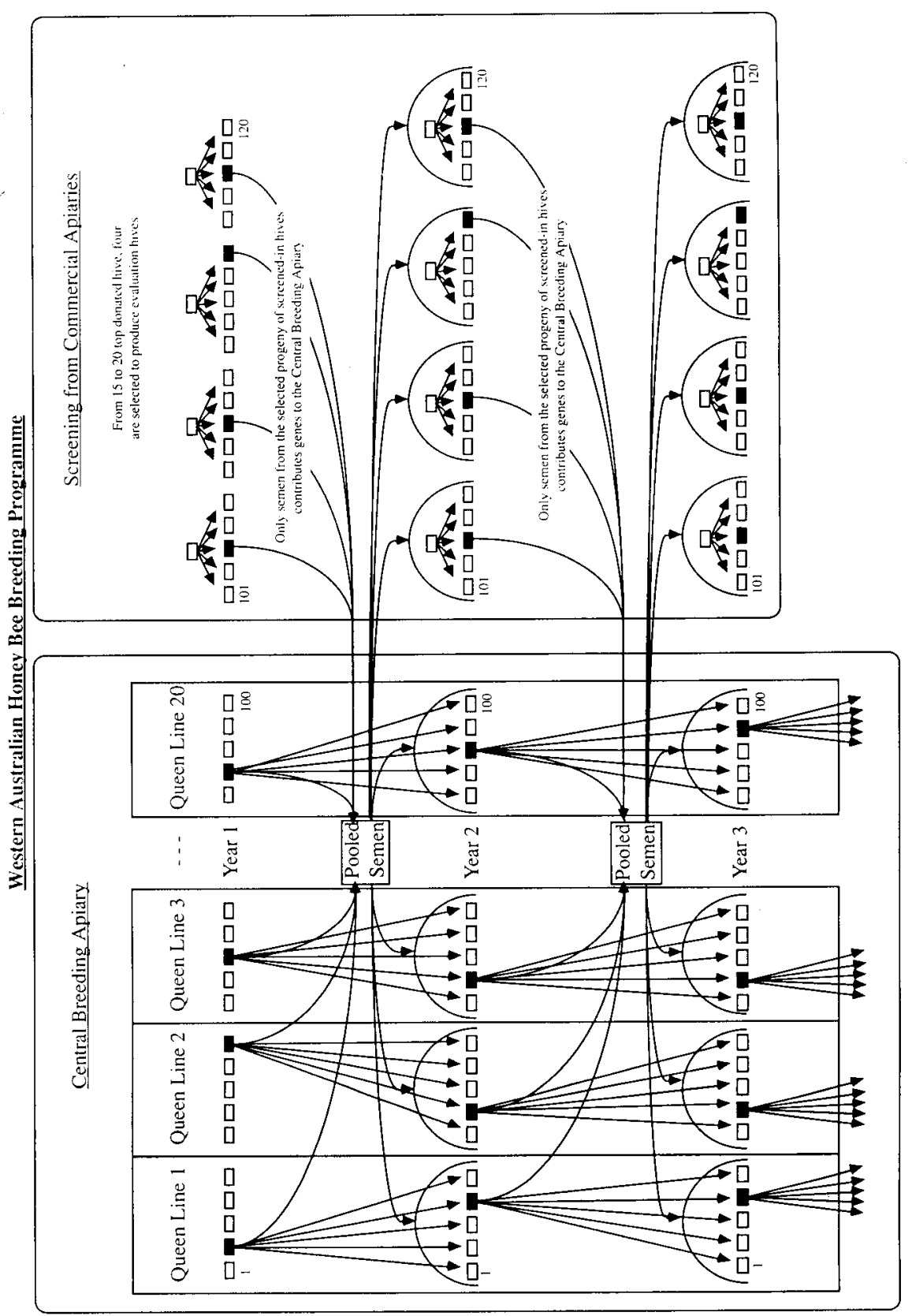

$\frac{1}{4} \div$

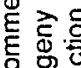

8 응

동ㅎㅁ음

원

동

过 范

듬

它

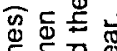

등 웡

요으

군은 흐

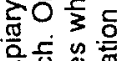

운웡 路

워

䗆

Ф文岕

穴完

전 윻 흔흥

등 콩

○莡

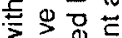

$=8$

可造灾要

号 응 六完

《文

$5: \frac{\pi}{2}$

诘文

广诘:

드 용

E음음

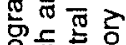

흔은 뒁

$030 \div$

등 苍要

녕응ㅎㅇ

\&

$\triangle$.

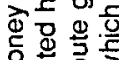

동

흥 등후

응 유

之敌哥

동 응 은 궁 흥 음 कส 은 뜽 过 
swing-out rotor. The diluted mixture was then centrifuged for 12 to $15 \mathrm{~min}$ at $1000 \mathrm{~g}$. The pure diluent formed a clear supernatant that was immediately decanted to avoid remixing. The Eppendorf tube was cut at the surface of the semen to withdraw it into the insemination syringe for II. Only the required amount for each day's inseminations was homogenized.

\section{Queen handling}

Queen cells were raised in queen right colonies according to Laidlaw and Eckert (1962). The queens were allowed to emerge and mature in nucleus colonies (4-frame Langstroth, with queen excluder at the entrance). After 5 days they were treated with $\mathrm{CO}_{2}$. The second $\mathrm{CO}_{2}$ treatment then occurred at the time of II (Ruttner, 1975) when each queen was inseminated with 10 to $12 \mu \mathrm{l}$ of homogenized semen and was returned to her colony. Two $\mathrm{CO}_{2}$ treatments initiate oviposition (Mackensen, 1947)). Queens were left undisturbed after II for 7 days until they started egg laying. The colonies were placed in 10-frame Langstroth hives and standardized (with 5 frames of brood, bees and the same amount of honey and pollen). After 6 weeks the evaluation period started, including honey production, brood viability, disease, temperament, color and other characteristics. The evaluation period for honey production depended upon the particular season. Since 1986, 7 queens have been inseminated to produce 5 in each line required for evaluation; the surplus was sold, kept or culled.

\section{RESULTS}

Over 5 years the rate of queens starting oviposition within 3 weeks after II was about $90 \%$ each year except for 1985 , when, presumably caused by queen infections, only $63 \%$ of the queens started egg laying (Table 1). Queen survival rate after the evaluation period in the colonies ranged from $62 \%$ to $87 \%$ (Table II). Start of oviposition ranged from 2-11 days in $1984,1-15$ days in 1985, 1-16 days in 1986 and $1-8$ days in 1987 (Fig. 2). The average was 4.35 days (S.E. $=0.15, n=$ 467). Brood viability was measured with a brood counting grid and was $88 \%$ in 1984 , $93 \%$ in 1985 and 1986 , and $94 \%$ in 1987 (S.E. = 0.66).

Honey production was estimated by weighing the numbered honey boxes with empty drawn frames before placing them on hives and again when removed. During the evaluation period (about 5 months : 3 to 4 honey flows) the 100 colonies within the central breeding nucleus (lines) pro-

Table I. Success rate of queens instrumentally inseminated with homogenized semen (three weeks after II).

\begin{tabular}{cccccc}
\hline & & \multicolumn{3}{c}{ Number of queens } \\
\cline { 3 - 5 } Year & $\begin{array}{c}\text { Total number } \\
\text { of II queens ( }(n)\end{array}$ & $\begin{array}{c}\text { Lost or } \\
\text { not laying }\end{array}$ & $\begin{array}{c}\text { Drone } \\
\text { layer }\end{array}$ & $\begin{array}{c}\text { Y Egg } \\
\text { laying }\end{array}$ & $\begin{array}{c}\text { Success } \\
(\%)\end{array}$ \\
\hline 1984 & 71 & 5 & 2 & 64 & 90 \\
1985 & 160 & 57 & 3 & 100 & 63 \\
1986 & 168 & 18 & 2 & 148 & 88 \\
1987 & 168 & 13 & 3 & 152 & 91 \\
1988 & 168 & 12 & 2 & 154 & 92 \\
\hline
\end{tabular}


Table II. Queen survival rate through colony evaluation.

\begin{tabular}{lcccccc}
\hline Year & $\begin{array}{c}\text { Evaluation } \\
\text { period } \\
\text { (month) }\end{array}$ & $\begin{array}{c}\text { Number of } \\
\text { evaluated } \\
\text { hives }\end{array}$ & Lost & Number of queens & $\begin{array}{c}\text { Survival } \\
\text { rate } \\
\text { (\%) }\end{array}$ \\
\cline { 5 - 7 } & & & & & & \\
\hline & 7 & 58 & 11 & 1 & 46 & 79 \\
1984 & 5 & 78 & 26 & 4 & 48 & 62 \\
1985 & 8 & 120 & 15 & -3 & 105 & 87 \\
1986 & 8 & 120 & 12 & 3 & 105 & 87 \\
\hline
\end{tabular}

duced $115 \mathrm{~kg}$ of honey in 1986/87 and 109 $\mathrm{kg}$ in $1987 / 88$ (S.E. $=2.80$ ). In 1986/87 the honey production of the 20 lines extended that of the progeny of the "screened-in queens" by more than $20 \mathrm{~kg}$ (both groups inseminated with identical semen). Before
1985 there was no difference between the groups. The average honey production in Western Australia (8-10 months) was 93 $\mathrm{kg}$ per productive hive in 1986/87 and 98 $\mathrm{kg}$ in 1987/88 (Australian Honey Board Report (Australian Bureau of Statistics)).

\section{START OF OVIPOSITION}
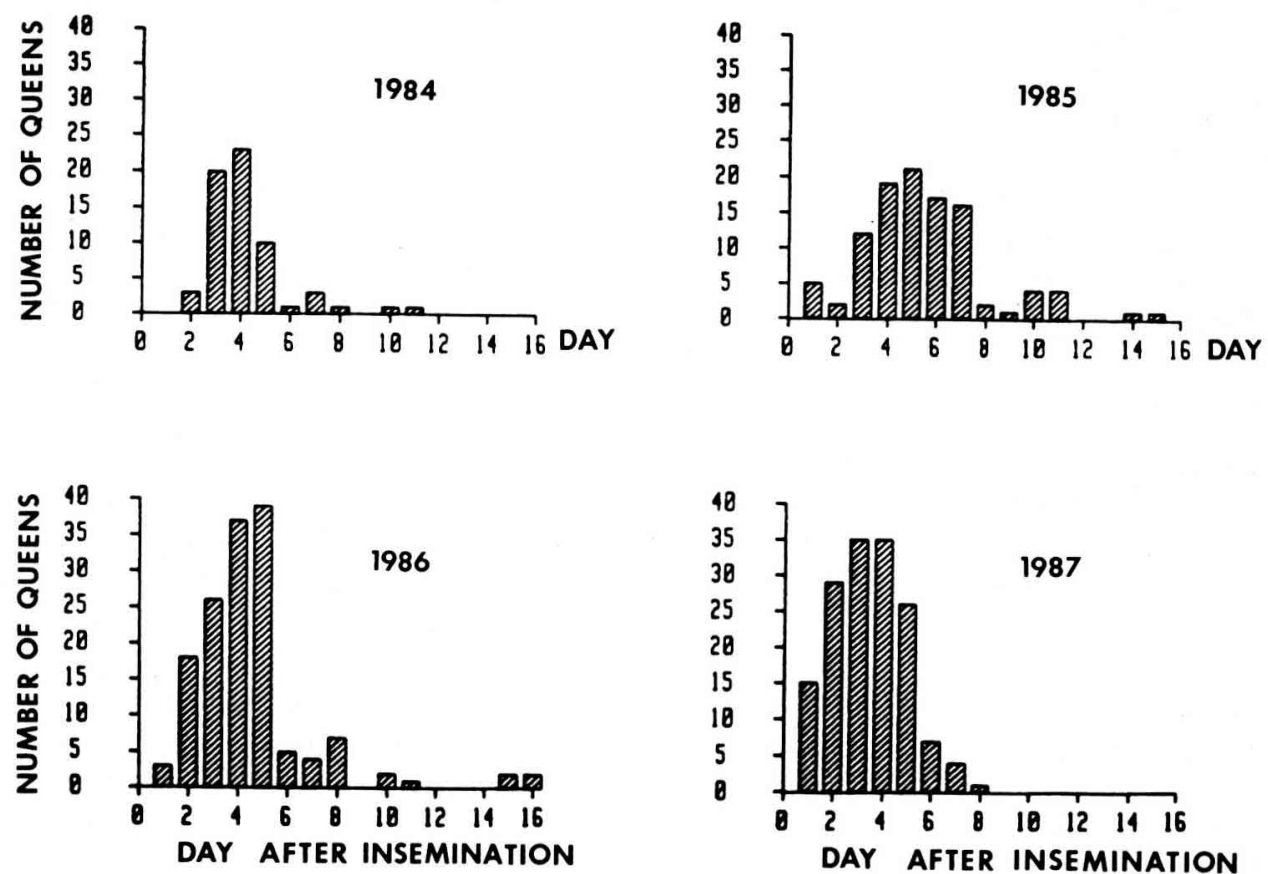

Fig. 2. Start of oviposition after instrumental insemination using homogenized drone semen. 


\section{DISCUSSION}

Using homogenized semen, the success rates are equal to or better than those reported from other II programs using the traditional technique (e.g. Severson et al, 1986; II success range: $38 \%-80 \%$, 8 month survival rate: $61 \%$ ).

In contrast to the results of Fisher (1987) the data from this program do not show a high rate of drone layers; actually in 1986 we were able to use breeder queens of 1984. This is an indication of the longevity of II queens. In the 1986 evaluation period, the equalized colonies built up to full size colonies within 6 weeks and produced honey 2 months after II. Honey production from the inseminated queens in the Western Australian breeding program (evaluated for a period of 4-5 months) compares favorably with the average honey production of naturally mated queens in the whole state. A marked disadvantage of II queens compared to open mated ones as found by Harbo and Szabo (1984) and Harbo (1986) was not evident.

Using Kiev diluent with the centrifuging technique, Kaftanoglu and Peng (1980, 1982) found a delay in the onset of oviposition $(1980=9.27 \pm 0.79$ days after post II $\mathrm{CO}_{2}, 1982=8.58 \pm 0.53$ days after II). The early start of oviposition in Western Australia (average 4.35 days after II) may be due to the use of Tris buffer to dilute the semen (Moritz, 1984b) as well as the program being conducted during peak spring conditions (Moritz and Kühnert, 1984).

With the usual II technique (Mackensen and Roberts, 1948; Ruttner, 1975) using Hyes saline solution as stopper fluid, Moritz and Kühnert (1984) found the onset of oviposition (1972-1983) averaged 7.69 days (S.E. $=0.07 ; n=3440$ ) which approximates the results of Kaftanoglu and Peng (1980, 1982) using Kiev with the Macken- sen technique. With Tris buffer as stopper fluid, in 1985 the onset of oviposition was $5.05 \pm 2.2$ days $(n=96)$ (Kühnert, unpublished data), which may indicate an accelerating effect of Tris buffer on the onset of oviposition, even when used as stopper fluid.

The risk of pooling large volumes of semen should be taken into consideration. One portion of infected or with drone fecal material contaminated semen may spoil the entire quantity of pooled semen. Low II results in 1985 may reflect queen infections due to contaminated semen. That year a group of technicians was trained to conduct the inseminations.

When using homogenized semen the following factors are important :

1) Mature, healthy drones: it is necessary to have exclusively mature drones in the colonies; preferably they should have defecated before they are used.

2) Aseptic conditions: strict precautions need to be taken to avoid any possible contamination. Preferably the semen collection should be carried out in a room separate from further sterile handling.

3) Appropriate dilution : the use of Tris buffer and dilution 1:12 was found to be suitable because the incidence of drone laying was low and brood viability was high.

4) Queen handling : queens should hatch and mature under optimal conditions before and after insemination (e.g. nucleus colonies). This is probably one of the most important factors for positive results (Woyke, 1979, 1988; Woyke and Jasinski, 1982).

The program as outlined in this paper is labor intensive and requires efficient organisation. Drone rearing from 24 lines and queen rearing from 20 lines plus "screening-in daughters" must be well coordinated. The data now available from this bee breeding program using the mixed 
semen technique for many years on a large scale indicate that the effort is rewarded through the improvement of bee stock. With a reasonable amount of additional equipment and extra attention paid to aseptic conditions, the semen mixing technique is a feasible method in bee breeding, and a way to counteract inbreeding.

The authors intend to publish a complete genetic analysis of the data after the results of the 1989 evaluation period become available.

\section{Résumé - Utilisation de spermes ho- mogénéisés dans le cadre d'un pro- gramme de sélection de l'abeille en Australie occidentale. Depuis 1984 on développe en Australie occidentale, avec le soutien et la collaboration de quelques apiculteurs professionnels, un projet de sé- lection basé sur un programme modifié par rapport au modèle de Page et al. (modèle de population fermée) et sur la technique des spermes mélangés pour l'insémination artificielle. On décrit ici la technique et on donne les résultats obtenus.}

La station centrale d'élevage comprend 100 ruches réparties en 20 lignées. Chaque année la reine la plus productive de chaque lignée fournit 5 reines filles. On constitue un pool d'insémination en prélevant une même quantité de sperme chez les mâles des diverses lignées et en mélangeant ces divers échantillons. Le nombre de mâles participant au pool d'insémination peut ainsi être considérablement augmenté et la consanguinité de ce fait diminuée. Les reines filles sont inséminées avec du sperme de ce pool; elles reçoivent donc toutes un mélange identique, ce qui autorise une évaluation précise de leurs performances. La méthode d'homogénéisation des spermes de mâles a été appliquée depuis 5 ans dans le programme de sélection décrit ici.

Du matériel génétique de reines non apparentées est continuellement introduit dans le pool d'insémination à partir de ruches fournies par la profession (Fig. 1). Le sperme des descendants les plus performants des 2 ruchers est mélangé et les jeunes reines de la station centrale d'élevage, de même que les filles des reines étrangères présélectionnées, sont inséminées avec du sperme homogénéisé de ce pool. Le sperme est prélevé chez des mâles âgés de plus de 16 jours, dans des capillaires de verre de $50 \mu \mathrm{l}$, obturé avec un diluant et conservé à $15^{\circ} \mathrm{C}$ durant 3 jours maximum. Comme diluant on utilise un tampon tris ainsi constitué : $\mathrm{NaCl}$ $(1,1 \%)$, glucose $(0,1 \%)$, monochlorure hydraté de L-arginine $(0,01 \%)$, monochlorure hydraté de $\mathrm{L}$-lysine $(0,01 \%)$ dissouts dans un tampon à $0,05 \mathrm{M}$ de tris-(hydroxyméthyl) amino-méthane et d'hydrochlorure de tris(hydroxyméthyl) amino-méthane ajustés au $\mathrm{pH} 8,7-8,9$. Peu de temps avant l'utilisation on ajoute du sulfate de streptomycine $(0,02 \%)$ et du sel G-K de pénicilline $(0,01 \%)$.

Des quantités égales de sperme de chaque lignée sont mélangées avec le diluant (12 fois le volume du sperme). Des tubes Eppendorf stériles $(0,4 \mathrm{ml})$ adaptés à des seringues jetables sans piston $(2 \mathrm{ml})$ servent de tubes à centrifuger pour une centrifugeuse de paillasse avec un rotor à bascule. Après 10-15 min de centrifugation à $1000 \mathrm{~g}$ (environ $2750 \mathrm{t} / \mathrm{min}$ pour la plupart des centrifugeuses de paillasse du commerce), le sperme se sédimente; on enlève la phase surnageante et, en coupant le tube Eppendorf à la surface du sperme, on récupère le sperme dans la seringue d'insémination. Les reines écloses dans les nuclei reçoivent à l'âge de 6 jours 10 à $12 \mu$ de sperme homogénéisé, après avoir été traitées la veille au $\mathrm{CO}_{2}$. 
En insémination de routine et en respectant des règles d'hygiène strictes, le taux de réussite a été d'environ $90 \%$ (Tableau I). La valeur plus faible de 1985 (1re année où deux nouveaux techniciens ont exercé cette technique) est vraisemblablement due à une infection des reines avec du sperme contaminé. La ponte a débuté en moyenne 4,35 jours après l'insémination (Fig. 2). Après la période d'évaluation ( 5 à 8 mois, soit 3 à 4 miellées) le taux de survie des reines maintenues dans des colonies sur 10 cadres a encore été de $78 \%$ en moyenne. II n'y a pas eu de reines bourdonneuses (Tableau II). Le taux de survie du couvain a varié de $88 \%$ (1984) à $94 \%$ (1987). Le développement des colonies a été rapide ( 6 semaines du nucleus 4 cadres à la colonie 10 cadres). Pendant une période d'évaluation de 4-5 mois (miellée principale), la production moyenne de miel à la station centrale d'élevage a été de $115 \mathrm{~kg}$ en 1986 et 109 $\mathrm{kg}$ en 1987. En 1986, les 100 reines filles des lignées ont produit en moyenne $20 \mathrm{~kg}$ de plus que les 20 filles des reines étrangères sélectionnées. Avant 1985 on n'a pas pu mettre en évidence de différence. La moyenne annuelle en Australie occidentale a été de $93 \mathrm{~kg}$ en 1986 et de 98 $\mathrm{kg}$ en 1987 pour des reines fécondées naturellement.

\section{Zusammenfassung - Anwendung der Spermamischtechnik in einem Bienen- zuchtprojekt in Westaustralien. Seit 1984 wird in Westaustralien mit Un- terstützung und Mitarbeit einiger Berufsim- ker ein Zuchtprojekt mit einem - ge- genüber dem Modell von Page und Mitarbeitern (closed population model) - abgeänderten Programm (open nucleus- Zuchtsystem) und der Spermamischtech- nik zur instrumentellen Besamung durch- geführt. Hier wird erstmals über Technik und bisherige Ergebnisse berichtet.}

Drohnensperma ist nach Aufschwemmung in geeignetem Verdünner und anschließendem Zentrifugieren gleichmäßig gemischt. Die Anzahl der zu einer Besamungsportion beitragenden Drohnen kann somit erheblich gesteigert und dadurch Inzucht gemindert werden. Alle Königinnen, die mit Samen aus derselben Mischprobe besamt werden, erhalten eine identische Mischung, was eine exaktere Leistungsprüfung der Königinnen zuläßt. Die Methode des Homogenisierens von Drohnensperma wurde in dem hier beschriebenen Zuchtprogramm seit 5 Jahren angewandt. Das Zuchtprogramm umfaßt eine zentrale Zuchtstation mit 20 Linien. Zuchtmütter für die nächste Generation werden nur aus diesen Linien selektiert. Über einen zweiten Prüfstand wird kontinuierlich unverwandtes Genmaterial über Drohnen zugeführt (Fig. 1). Sperma der leistungsfähigsten Nachkommen beider Stände wird gemischt und sowohl die Jungköniginnen der zentralen Zuchtstation, als auch die Töchter der vorselektierten fremden Königinnen werden mit homogenisiertem Sperma aus dieser Mischprobe besamt. Letztere dienen ausschließlich zur Drohnenproduktion. Geschlechtsreife Drohnen (älter als 16 Tage) werden in Abfangzargen ins Labor gebracht. Das in $50 \mu$-Glaskapillaren aufgenommene Sperma wird (nach Verschließen mit Verdünner) maximal 3 Tage bei $15^{\circ} \mathrm{C}$ gelagert. Als Spermaverdünner dient ein Trispuffer, der folgendermaßen hergestellt werden kann : Natrium Chlorid $1,1 \%$, Glukose $0,1 \%$, L-Argininmonohydrochlorid $\quad 0,01 \%$, L-Lysinmonohydrochlorid 0,01\% (Fa. Merck, Darmstadt), werden gelöst in einem 0,05 M Puffer aus Tris(hydroxymethyl)aminomethan, und Tris(hydroxymethyl)aminomethanhydrochlorid (Fa. Sigma, München), so daß ein $\mathrm{pH}$ von 8,7 bis 8,9 entsteht. Kurz vor Verwendung wird $0.02 \%$ Streptomycin Sulfat und 0,01\% Penicillin G-K Salz (Fa. 
Merck) zugegeben. Die gleiche Menge Sperma jeder Drohnensorte wird in Kapillaren aufgenommen und anschließend mit der 12-fachen Menge Verdünner gründlich gemischt. Die Hülse einer $2 \mathrm{ml}$ Einwegspritze mit aufgestecktem, sterilem $0.4 \mathrm{ml}$-Eppendorfgefäß (Weichplastik) dient als Zentrifugenröhrchen in einer Tischzentrifuge mit Schwingrotor. Nach 10-15 min Zentrifugation bei $1000 \mathrm{~g}$ (ca. $2750 \mathrm{U} / \mathrm{pm}$ in den meisten handelsüblichen Tischzentrifugen) sedimentiert das Sperma und kann nach Entfernen des Überstandes (bzw. Durchschneiden des Eppendorfgefäßes an der Spermaoberfläche) in die Besamungskanüle aufgenommen werden. Am 6. Lebenstag erhalten die in Ablegern geschlüpften und tags zuvor mit $\mathrm{CO}_{2}$ behandelten Königinnen 10-12 $\mu \mathrm{l}$ des homogenisierten Spermas.

Bei strikter Einhaltung strenger Hygienemaßnahmen und routinierter Besamungstechnik wurde ein Besamungserfolg von ca. $90 \%$ erreicht (Tab. I). Der niedrigere Wert von 1985, (dem ersten Praxisjahr neuer Besamungstechniker) ist möglicherweise auf eine infektion der Königinnen mit kontaminiertem Sperma zurückzuführen. Der Eilagebeginn lag durchschnittlich 4,35 Tage nach der Besamung (Fig. 2). Die Überlebensrate der bei ausgezeichneter Tracht in Vollvölkern gehaltenen Königinnen betrug nach fünf bis acht Leistungsprüfungsmonaten (3-4 Trachten) noch durchschnittlich $76 \%$. Es wurde kaum Drohnenbrütigkeit registriert (Tab. II). Die Brutüberlebensrate steigerte sich von $88 \%$ (1984) auf $94 \%$ (1987). Die Volksentwicklung war zügig (6 Wochen vom 4-Waben Ableger zum Vollvolk). Innerhalb einer Prüfperiode von 4-5 Monaten (Haupttracht) lag die durchschnittliche Honigproduktion der Nachkommen innerhalb der zentralen Zuchtstation (100 Völker) 1986 bei $115 \mathrm{~kg}$ und 1987 bei 109 $\mathrm{kg}$ (letzteres gesammelt in einer Trachtperiode von 6-8 Wochen mit Spitzenleistungen von $175 \mathrm{~kg}$ ). Diese 100 Linientöchter produzierten damit 1986 durchschnittlich um $20 \mathrm{~kg}$ Honig mehr als die 20 Töchter der Zuchtköniginnen, die von Imkern zur Verfügung gestellt wurden (beide Gruppen waren mit identischem Sperma besamt). Vor 1985 war noch kein Leistungsunterschied festzustellen. Der landesweite Jahresdurchschnitt in Westaustralien betrug bei standbegatteten Königinnen $93 \mathrm{~kg}$ für 1986 und $98 \mathrm{~kg}$ für 1987.

\section{ACKNOWLEDGMENTS}

The funds provided by the Australian Honey Research Committee and the assistance given by the Western Australian Department of Agriculture, especially that of the beekeeping crew, are gratefully acknowledged. We are grateful to Professor F. Ruttner and Professor H. Koeniger and for encouraging discussions, and wish to thank Drs S. Fuchs, R. Hellmich and B. Ch. BrandesFrisch for help with the manuscript. Thanks also go to Gretchen Wheen from NSW, Australia, who gave support in many ways.

\section{REFERENCES}

Chevalet C. \& Cornuet J.-M. (1982a) Etude théorique sur la sélection du caractère "production de miel" chez l'abeille. I. Modèle génétique et statistique. Apidologie 13, 39-65

Chevalet C. \& Cornuet J.-M. (1982b) Evolution de la consanguinité dans une population d'abeilles. Apidologie 13, 157-168

Fischer F. (1987) Untersuchungen zum Einfluß der Spermamischtechnik auf den Füllungsgrad der Spermatheka. Im: Bericht über die Tagung der Arbeitsgemeinschaft der Institute (1987, Mayen). Apidologie 18, 360-362 
Harbo J.R. (1985) Instrumental insemination of queen bees - 1985. Am. Bee J. 125, 197-202; 282-287

Harbo J.R. (1986) Oviposition rates of instrumentally inseminated and naturally mated queen honey bees (Hymenoptera: Apidae). Ann. Entom. Soc. Am. 79, 112-115

Harbo J.R. \& Szabo T.I. (1984) A comparison of instrumentally inseminated and naturally mated queens. J. Apic. Res. 23, 31-36

Kaftanoglu O. \& Peng Y.-S. (1980) A washing technique for collection of honeybee semen. $J$. Apic. Res. 19, 205-211

Kaftanoglu O. \& Peng Y.-S. (1982) Effects of insemination on the initiation of oviposition in the queen honey bee. J. Apic. Res. 21, 3-6

Laidlaw H.H. Jr. (1985) Disposable syringe for shipment of bee semen. Am. Bee J. 125, 368369

Laidlaw H.H. Jr. \& Eckert (1962) Queen rearing. University of California Press, CA

Mackensen O. (1947) Effect of carbon dioxide on initial oviposition of artificially inseminated and virgin queen bees. J. Econ. Entomol. 40, 344-349

Mackensen O. (1951) Vitality and sex determination in the honey bee (Apis mellifera $L$ ). Genetics 36, 500-509

Mackensen O. \& Roberts W.C. (1948) A manual for the artificial insemination of queen bees. U.S.D.A. Bur. Ent. Plant Quar. ET-250

Moran C. (1983) Sex-linked effective population size in control populations, with particular reference to honeybees. Theor. Appl. Genet. 67, 317-322

Moritz R.F.A. (1981) Der Einfluß der Inzucht auf die Fitness der Drohnen von Apis mellifera carnica. Apidologie 12, 41-55

Moritz R.F.A. (1983) Homogenous mixing of honeybee semen by centrifugation. J. Apic. Res. 22, 249-255

Moritz R.F.A. (1984a) Selection in small populations of the honeybee. Z. Tierz. Züchtgsbiol. 101, 394-400

Moritz R.F.A. (1984b) The effect of different diluents on the insemination success in the honeybee using mixed semen. J. Apic. Res. 23, 164167
Moritz R.F.A. \& Kühnert M.E. (1984) Seasonal effects on artificial insemination of honeybee queens (Apis mellifera L.). Apidologie 15, 223231

Page R.E. Jr. \& Laidlaw H.H. Jr. (1982a) Closed population honeybee breeding. I. Population genetics of sex determination. J. Apic. Res. 21, 30-37

Page R.E. Jr. \& Laidlaw H.H. Jr. (1982b) Closed population honeybee breeding. 2. Comparative methods of stock maintenance and selective breeding. J. Apic. Res. 21, 38-44

Page R.E. Jr. \& Marks R.W. (1982) The population genetics of sex determination in honeybees : random mating in closed populations. Heredity 48, 263-270

Page R.E. Jr., Erickson E.H. \& Laidlaw H.H. Jr. (1982) A closed population breeding programme for honey bees. Am. Bee J. 122, 350351; 354-355

Page R.E. Jr., Laidlaw H.H. Jr. \& Erickson E.H. Jr. (1983) Closed population honeybee breeding. 3. The distribution of sex alleles with gyne supersedure. J. Apic. Res. 22, 184-190

Plass F. (1953) Inzuchtwirkung und Heterosiseffekt bei der Honigbiene. Allg. Inform. Dienst. 66, 49-68

Poole H.K. \& Taber S.III (1970) In vitro preservation of honey bee semen enhanced by storage at $13-15^{\circ} \mathrm{C}$. Ann. Entomol. Soc. Am. 63, 1673-1674

Ruttner F. (1975) Die instrumentelle Besamung der Bienenkönigin. Apimondia Publishing House, Bucharest

Ruttner F. (1980) Aufzucht und Pflege der Drohnen. In : Königinnenzucht, biologische Grundlagen und technische Anleitungen. (Harnaj V. \& Ruttner F. eds.) Apimondia-Verlag, Bukarest

Schley P. (1983) Praktische Anleitung zur instrumentellen Besamung von Bienenköniginnen. WSE Selbstverlag.

Severson D.W., Page R.E. \& Erickson E.H. Jr (1986) Closed population breeding in honeybees : a report on its practical application. $A m$. Bee J. 126, 93-94

Verma L.R. (1978) Biology of honeybee spermatozoa. 1. Effect of different diluents on mortility and survival. Apidologie 9, 167-173 
Williams J.L. \& Harbo J.R. (1982) Bioassay for diluents of honeybee semen. Ann. Entomol. Soc. Am. 75, 157-159

Woyke J. (1979) Effect of the access of worker honey bees to the queen on the results of instrumental insemination. J. Apic. Res. 19, 136-143
Woyke J. (1988) Problems with queen banks. Am. Bee. J. 4, 276-278

Woyke J. \& Jasinski Z. (1982) Influence of the number of attendant workers on the number of spermotozoa entering the spermatheca of instrumentally inseminated queens kept outdoors in mating nuclei. J. Apic. Res. 21, 129-133 